\title{
Corruption and Human Rights
}

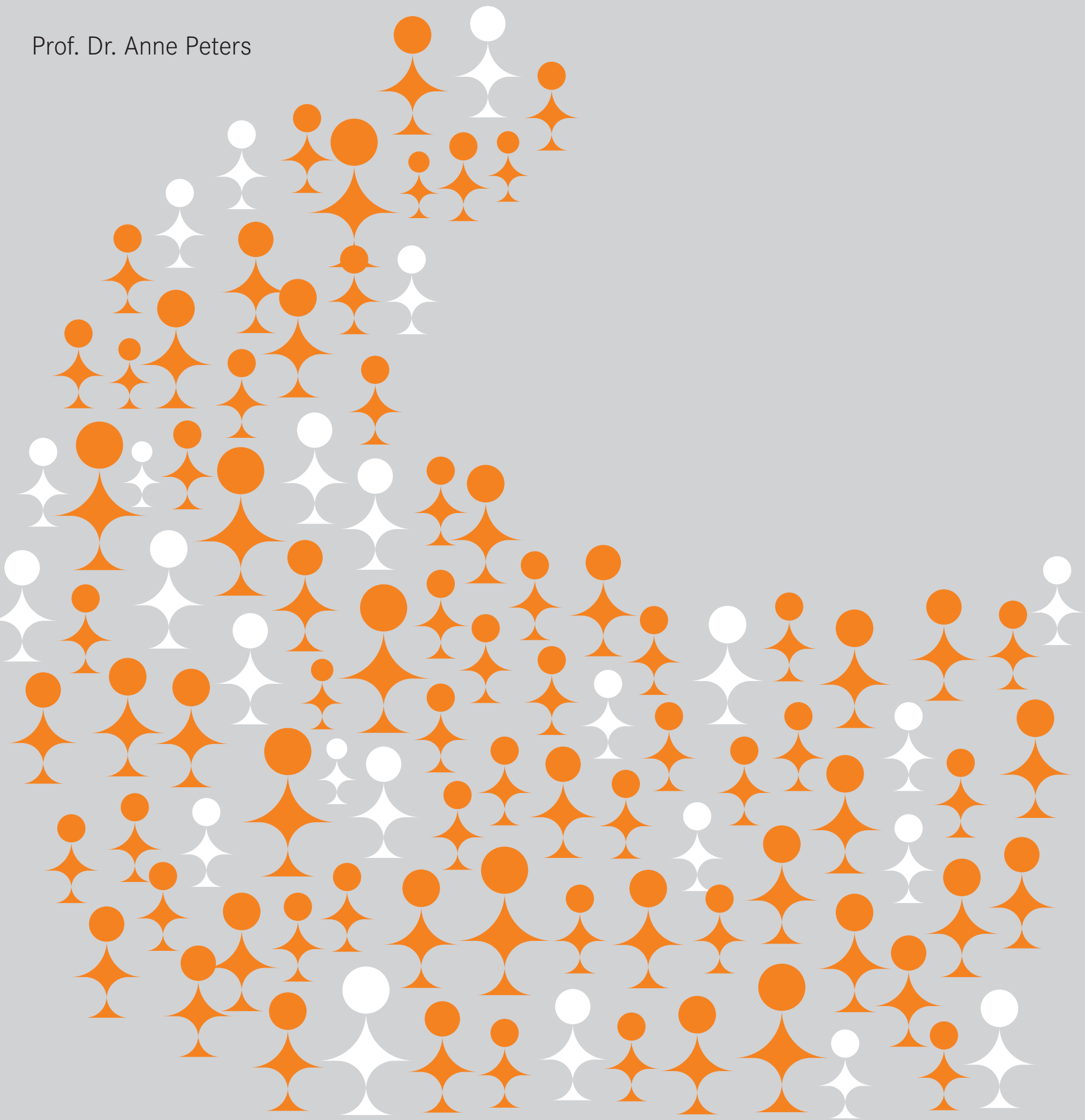


Basel Institute on Governance Working Paper 20. ISSN: 2624-9650.

(c) Basel Institute on Governance, September 2015

Responsibility for the views expressed and for any errors of fact or judgment rests with the author alone. 


\section{Corruption and Human Rights}

Prof. Dr. Anne Peters*

* Director at the Max-Planck-Institute for Comparative Public Law and Public International Law, Heidelberg (Germany), professor at the universities of Heidelberg, Freie Universität Berlin, and Basel (Switzerland) and Vice-President of the Board of the Basel Institute on Governance. I would like to thank Prof. Dr. Mark Pieth and Gretta Fenner of the Basel Institute and the participants in my research seminar at the Max Planck Institute for the valuable discussions on the topic as well as my student research assistants for their support. 



\title{
Table of contents
}

\author{
INTRODUCTION AND PROBLÉMATIQUE 7
}

TERMS AND FACTS 10

CAN CORRUPTION BE CONCEPTUALIZED AS A VIOLATION OF HUMAN RIGHTS? 11

Whose human rights? 11

Which human rights? 11

Human rights violations 12

What State action? Violations of what obligations? 12

Corruption as a violation of the fundamental obligations set out in Article 2(1) ICESCR 16

Causation of the human rights violation 18

Attribution to the State 21

Special aspects of determining a violation of the prohibitions of discrimination 23

Weak anti-corruption measures as an inherent limitation or a legal restriction of human rights

covered by the margin of appreciation? 24

\section{SHOULD CORRUPTION BE CONCEPTUALIZED AS A HUMAN RIGHTS VIOLATION? 26}

Opportunity for moral and practical strengthening of the anti-corruption agenda 26

Practical recommendations 27

Risk of moral weakening 27

\section{CONCLUSION AND OUTLOOK 29}

Shift in the prerogative of interpretation 29

Devaluation of the Global South? 29

The State, public office, and universalizability 29 


\section{Introduction and problématique}

In May 2015, seven high-ranking officials of FIFA, the Fédération Internationale de Football Association, including the FIFA vice president, were arrested in Zurich on suspicion of corruption pursuant to a US warrant. They were accused of having accepted more than USD 150 million in exchange for awarding football tournaments since 1999. It may be assumed, for instance, that South Africa remunerated FIFA officials in order to be chosen to host the 2010 FIFA World Cup. In preparation for that world championship, living huts were destroyed to make way for new construction projects, and homeless people were "removed" and forced to relocate. Street vendors without a FIFA permit were not admitted and, in extreme cases, were arrested if they violated the requirement. ${ }^{1}$ South African Facebook users reacted to the arrests with the comment: "South Africa bribed for the World Cup - but it was totally worth it”.

The FIFA scandal illustrates two political and potential moral problems: First, the legal nexus between corruption and human rights may pillory the Global South while neglecting corruption in developed countries. Although Western host countries such as Germany probably also used dishonest means to influence FIFA officials, Germany was not accused in regard to the 2006 World Cup - unlike South Africa, Brazil, and Qatar.

Secondly, the South African Facebook comments indicate that the average citizen does not necessarily consider corruption to be an abhorrent evil that must be eradicated - a "cancer", as World Bank president James Wolfensohn said in $1996^{2}$ - as part of a global anti-corruption campaign. Terms such as "palm grease" and "speed money" show that even just a few decades ago, most societies at least tolerated informal payments to lubricate the gears of economic and social life and to accelerate its operations. But even at the price of human rights violations?

1 Amnesty International, Human rights concerns in South Africa during the World Cup, 4 June 2010.

2 Speech on "People and Development" by World Bank president James D. Wolfensohn, Annual Meetings Address of 1 October 1996.
Already the preamble of the French Declaration of the Rights of Man and of the Citizen of 26 August 1789 stated that "the ignorance, neglect, or contempt of the rights of man are the sole cause of public calamities and of the corruption of governments". Here, the violation of human rights is seen as the cause of corruption (in the broadest sense). Is the converse also true?

Empirically, it can be shown that countries with high rates of corruption (or high levels of corruption perception) are also the countries with a poor human rights record. ${ }^{3}$ For instance, the countries at the bottom of the most recent list of 173 countries ranked by Transparency International, the Corruption Perception Index of 2014, are Sudan, North Korea, and Somalia. Is is safe to say that corruption and human rights violations thrive in the same environments and probably have the same root causes, such as poverty and weak institutions.

The question is now whether a particular legal nexus can be identified beyond this coincidence of corruption and

3 For a statistical analysis, see Todd Landman/Carl Jan Willem Schudel, Corruption and Human Rights, Empirical Relationships and Policy Advice, Working Paper (International Council on Human Rights Policy: Geneva 2007), controlling for other explanatory variables (democratic level; prosperity, population size, and government spending ratio). There are of course numerous human rights violations that have nothing to do with corruption, such as discrimination against women. Conversely, there are forms of corruption that have few if any links to human rights, such as illegal funding of political parties. 
inadequate protection of human rights. ${ }^{4}$ This question is of practical relevance because the international anti-corruption instruments that have been adopted and implemented since 1997 - at least ten international and regional treaties with various additional protocols as well as soft law ${ }^{5}$ - have

4 For a first study, see Zoe Pearson, An International Human Rights Approach to Corruption, in: Peter Larmour and Nick Wolanin (eds.), Corruption and Anti-Corruption (Canberra 2001), 30-61. See also, fundamentally, International Council on Human Rights Policy and Transparency International (prepared by Magdalena Sepúlveda Carmona), Corruption and Human Rights: Making the Connection (Geneva: International Council on Human Rights Policy 2009); Martine Boersma/Hans Nelen (eds.), Corruption and Human Rights: Interdisciplinary Perspectives (Cambridge: Intersentia 2010); Martine Boersma, Corruption: A Violation of Human Rights and a Crime Under International Law? (Cambridge: Intersentia 2012); Kolale Olaniyan, Corruption and Human Rights Law in Africa (Oxford: Hart 2014).

5 Inter-American Convention against Corruption of 29 March 1996, in force since 3 June 1997; OECD Convention on Combating Bribery of Foreign Public Officials in International Business Transactions of 17 December 1997, in force since 15 February 1999 (41 parties as of June 2015). Council of Europe: Criminal Law Convention on Corruption of 27 January 1999 (ETS No. 173); Additional Protocol of 15 May 2003 (ETS No. 191), in force since 1 February 2005; Civil Law Convention on Corruption of 4 November 1999 (ETS No. 174); Group of States against Corruption (GRECO), since 1999 (49 member States as of July 2015). Committee of Ministers: Recommendation No. R (2000)10 on Codes of Conduct for Public Officials of 11 May 2000; Recommendation Rec. (2003) 4 on Common Rules against Corruption in the Funding of Political Parties and Electoral Campaigns of 8 April 2003; United Nations Convention against Corruption of 31 October 2003 (UNCAC), in force since 14 December 2005, UNTS vol. 2349, p. 41 (UN Doc. A/58/422), 175 States parties (as of 1 April 2015), Germany ratified in 2014. In the EU: Convention drawn up on the basis of Article K.3 of the Treaty on European Union, on the protection of the European Communities' financial interests (CFPI Convention) of 26 July 1995, No. C 316/49, 27/11/1995, in force since 17 October 2002; Convention drawn up on the basis of Article K.3 of the Treaty on European Union, relating to extradition between the Member States of the European Union No. C 313/12, 23/10/1996, in force since 17 October 2002; Convention drawn up on the basis of Article K.3 (2) (c) of the Treaty on European so far been only moderately successful. For instance, only about four of the currently 41 States parties to the OECD Anti-Bribery Convention are truly "active" in their implementation. ${ }^{6}$ The number of criminal convictions for domestic and foreign bribery is notoriously low worldwide; corruption continues to be associated with impunity. The enforcement of international anti-corruption norms must therefore be improved - at least on the assumption that these norms are sensible and legitimate. This could be done with the help of human rights arguments and instruments.

\section{The nexus between corruption and human rights violations ${ }^{7}$}

Union on the fight against corruption involving officials of the European Communities or officials of Member States of the European Union of 26 May 1997, No. C 195/2 25/06/1997, in force since 17 October 2002; European Commission, Communication on Fighting Corruption of 6 June 2011 (COM (2011) 308 final). Africa: African Union Convention on Preventing and Combating Corruption of 11 July 2003, in force since 4 August 2006; Southern African Development Community (SADC) Protocol against Corruption of 14 August 2001, in force since 6 July 2005. In the literature, see Julio Bacio Terracino, The International Legal Framework against Corruption: States' Obligations to Prevent and Repress Corruption (Antwerp: Intersentia 2012); Jan Wouters, Cedric Ryngaert, Ann Sofie Cloots, The International Legal Framework against Corruption: Achievements and Challenges, Melbourne Journal of International Law 14 (2013), 209-280.

6 Transparency International, Exporting Corruption: Progress Report 2014: Assessing Enforcement of the OECD Convention on Combating Foreign Bribery. The four "active" countries are the United States, the United Kingdom, Germany, and Switzerland.

7 Two other links between corruption and human rights will not be discussed in detail here: First, the effective protection of (some) human rights (especially freedom of access to information and freedom of the press) is indispensable for combating corruption. Another link is that anti-corruption measures may themselves violate human rights (violation of the presumption of innocence, especially in the implementation of Article 20 UNCAC, violation of the right to a private life through the use of liaisons and surveillance, damage to reputation through disclosures in the media, violations of property through seizures and asset recovery (see Radha Ivory, Corruption, Asset Recovery, and the Protection of Property in Public International Law (Cambridge University Press 2014)). 
is thus of practical relevance - but is it not trivial in theoretical terms? Corruption means that administrative or political decisions by government authorities are bought rather than made on the basis of lawfulness in procedures formally envisaged for that purpose. Corruption follows the unofficial laws of the market, thereby circumventing the rule of law. Because corruption is thus the antithesis to the rule of law, and because the rule of law in turn is a necessary condition for the respect of human rights, then corruption - in a very general sense - constitutes the negation of the idea of human rights. Hence, there not only exists a nexus, but even almost a tautology.

It is an entirely different question, however, whether corrupt acts in fact violate specific human rights in specific cases, such that a complaint against the violation might be made with the help of the established national and international procedures, or even such that legal action might be taken. I will investigate this problem in the form of a double question: Can corrupt conduct be conceptualized as a violation of human rights in a systemically compatible way? And secondly: Should corrupt acts be classified and punished as human rights violations? My answer is that under certain preconditions, we can undertake such a legal construction, especially in cases of petty corruption, but that we should do so only within limits - and with awareness of the risks. 


\section{Terms and facts}

Corruption $^{8}$ is not a technical term; it is not considered a criminal offence in most criminal codes around the world and it also does not have a legal definition in most international treaties. The most common definition is that used by the NGO Transparency International, according to which corruption is the abuse of entrusted power for private gain. Such abuse may happen on the level of day-to-day administration and public service ("petty corruption"), or on the high level of political office ("grand corruption"). These terms do not mark a legal distinction but merely describe variations of the same theme. Often, a particular scheme of corruption permeates the various levels of public administration, and thus links both forms of corruption.

Because of the growing power of large corporations and nonState actors such as FIFA, the abuse of obligations arising from private law - in a "private" principal-agent relationship - is also increasingly qualified as corruption. The relevant criminal offences are active and passive bribery, criminal breach of trust, graft, illicit enrichment, and so on. In the private sector, offences include anti-competitive practices and regulatory offences.

The 172 ratifications of the UN Convention against Corruption (UNCAC), ${ }^{9}$ which was adopted in 2003, shows that States around the world are - at least verbally - committed to the international fight against corruption. This appears to be a logical reaction to the fact of globalization, due to which practically all cases of grand corruption have a transnational element. In the 1990s, the United States achieved adoption of a treaty to criminalize foreign bribery, namely the OECD Anti-Bribery Convention of 1997. The primary goal at the time was to eliminate the unfair competitive advantages of companies paying bribes in the new markets

8 See Mark Pieth, Chapter 2: A Very Short Introduction to Corruption, in: Fritz Heimann/Mark Pieth, Confronting Corruption (New York: Oxford UP 2016).

9 N. 5. especially of Eastern Europe. ${ }^{10}$ Today, the international leading authority on corruption mentions the following goal of international anti-corruption policy: firstly, to improve the functioning of the global markets; secondly, to promote economic growth; thirdly, to reduce poverty; and fourthly, to safeguard the legitimacy of the State. ${ }^{11}$ Anti-corruption has largely been merged with the good governance agenda and the development discourse, ${ }^{12}$ and good governance - as well as development - is nowadays often analysed through a human rights lens.

10 See Mark Pieth, Strafzweck: Warum bestrafen wir Auslandsbestechung?, in: Elisa Hoven/Michael Kubiciel (eds.), Das Verbot der Auslandsbestechung (Baden-Baden: Nomos 2015).

11 See Susan Rose-Ackerman, Introduction: The Role of International Actors in Fighting Corruption, in: Rose-Ackerman/Paul Carrington (eds.), Anti-Corruption Policy: Can International Actors Play a Constructive Role? (Durham: Carolina Academic Press 2013), 3-38, 5. See also the preamble of UNCAC 2003 (n. 5), first preambular paragraph.

12 See, e.g., Human Rights Council, "The role of good governance in the promotion and protection of human rights" of 27 March 2008, para.

4: "Decides to continue its consideration of the question of the role of good governance, including the issue of the fight against corruption in the promotion and protection of human rights, [...]" (UN Doc. A/HRC/ RES/7/11). See also UN Development Programme - Oslo Governance Centre, The Impact of Corruption on the Human Rights Based Approach to Development (2004). 


\section{Can corruption be conceptualized as a violation of human rights?}

\section{Whose human rights?}

Traditionally, bribery was considered a "victimless crime". ${ }^{13}$ According to doctrine, the public was considered the injured party. Moreover, the core of bribery is a "wrongful agreement". ${ }^{14}$ Can the briber, who often even takes the initiative, be considered a victim? In my view, this is plausible in the case of petty corruption. If the graduate of a public school has to pay the secretary a bribe to receive her diploma, or if she has to pay for additional private lessons from a teacher who indicates that she will not pass the examination otherwise, then she is a victim - not a perpetrator - at least in terms of human rights. Her consent to the illegal quid pro quo is the result of a desperate situation; the consent of the student (or of her parents) is not "free", but rather coerced.

In public procurement, the economic sector most susceptible to corruption - the EU estimates that approximately $13 \%$ of all budget spending for public procurement is lost ${ }^{15}$ -, the unsuccessful competitors are the potential victims if they are not awarded the contract due to extraneous criteria, at least if they have a concrete expectancy to the contract and not merely abstract prospects. Clients and end users are of course also adversely affected by corruption in public procurement if they have to pay higher prices or if they receive a product that is not worth the money because funds have been diverted during the production process.

In the political process, voters are adversely affected by candidates' financial dependence on major donors if the candidates are politically indebted to the donors after the election and if voters are unaware of those vested interests.

13 Matthias Korte in Wolfgang Joecks/Klaus Miebach (eds.), Münchener Kommentar zum StGB, 2nd ed. Munich 2014, § 331, para. 12.

14 In German criminal law since German Federal Court of Justice, BGH St. 15, 88-103, 97 of 25 July 1960; more recently, see, e.g., BGH, 3 StR 212/07 of 28 August 2007, para. 29, reprinted in NJW 2007, 3446 (3447).

15 PricewaterhouseCoopers, Study prepared for the European Anti-Fraud Office (OLAF), Public Procurement: costs we pay for corruption. Identifying and Reducing Corruption in Public Procurement in the EU (2013).
The question is now whether those persons who are affected directly or indirectly are sufficiently individualised, and whether human rights are actually at stake in these scenarios.

\section{Which human rights?}

This is not about any (new) human right to a corruption-free society. ${ }^{16}$ Such a right is neither recognized by legal practice nor is there a need for it. Rather, corruption affects the recognized human rights as they have been codified by the UN human rights covenants. In practice, what is most often affected are social rights, especially by petty corruption. For example, corruption in the health sector affects the right of everyone to the highest attainable standard of health (Article 12 ICESCR); in the education sector, the right to education (Article 13 ICESCR) is at issue.

But also the classical liberal human rights may be undermined by corruption: If a prisoner has to give the guard something in return for a blanket or better food, then the prisoner's basic right to humane conditions of detention (Article 10 ICCPR) is affected. If - as most observers tend to think - the current surge in human trafficking is made possible and facilitated primarily by corruption that induces police and border guards to look the other way, then this affects the human right to protection from slavery and servitude (Article 18 ICCPR). Obviously, corruption in the administration of justice endangers the basic rights to judicial protection, including the right to a fair trial without undue delay (Article 14 ICCPR). In the case of grand corruption and foreign bribery, however, the implications for human rights - such as the effect of nepotism on the right to equal access to public offices (Article 25(a) ICCPR) - are less clear.

16 But see Ndiva Kofele-Kale, The Right to a Corruption-Free Society as an Individual and Collective Human Right: Elevating Official Corruption to a Crime under International Law, International Lawyer 34 (2000) 149-178; Andrew Brady Spalding, Corruption, Corporations and the New Human Right, Washington University Law Review 91 (2014), 1365-1428. 


\section{Human rights violations?}

The third doctrinal question is whether it even makes sense to speak of human rights violations. In the predominant practice of the United Nations, only weaker vocabulary is used to make the connection, both in the strategic documents - such as the new reports of the Human Rights Council and in the country-, issue-, or individual case-specific monitoring practice of the treaty bodies and the Charter-based Human Rights Council. ${ }^{17}$ Almost all the texts refer only to a "negative impact" on the enjoyment of human rights, ${ }^{18}$ or state that corruption "undermines" human rights, ${ }^{19}$ or em-

17 But for a determination of "violations", see the foreword to UNCAC (2003) by UN Secretary-General Kofi Annan: "Corruption is an insidious plague that has a wide range of corrosive effects on societies. It undermines democracy and the rule of law, leads to violations of human rights, distorts markets, erodes the quality of life and allows organized crime, terrorism and other threats to human security to flourish" (italics mine); UN Human Rights Commission, Corruption and its impact on the full enjoyment of human rights, in particular, economic, social and cultural rights, Preliminary report of the Special Rapporteur, Ms. Christy Mbonu of 7 July 2004 (UN Doc. E/CN.4/Sub.2/2004/23), para. 57: “corruption, whether systemic, endemic or petty, violates citizens' enjoyment of all the rights contained in all the international instruments" (italics mine); ibid., Progress report submitted by the Special Rapporteur, 22 June 2005 (UN Doc. E/CN.4/Sub.2/2005/18), para. 24: “A fundamental right is violated if, due to poverty, vote-buying by political parties denies the electorate from voting for the best candidates" (italics mine).

18 Human Rights Council, Res. 29/11 "The negative impact of corruption on the enjoyment of human rights" of 2 July 2015; Final Report of the Human Rights Council Advisory Committee on the issue of the negative impact of corruption on the enjoyment of human rights (UN Doc. A/ HRC/28/73) of 5 January 2015, especially para. 21; Opening statement by Navi Pillay, High Commissioner for Human Rights, Panel on "the negative impact of corruption on human rights" of 13 March 2013, in: United Nations Human Rights: Office of the High Commissioner, 8-10 (8).

19 UN Human Rights Commission, Sub-Commission: "Deeply concerned that the enjoyment of human rights, be they economic, social and cultural or civil and political, is seriously undermined by the phenomenon of corruption" (Sub-Commission on the Promotion and Protection of Human Rights, Resolution of 5 August 2005, E/CN.4/Sub.2/2005/L.24/ phasize the "grave and devastating effect" of corruption on the enjoyment of human rights. ${ }^{20}$

Those domestic courts that have significantly shaped the legal contours of social human rights, namely the Indian and South African constitutional courts, tend to assert rather than justify that corruption violates human rights. For instance, the Constitutional Court of South Africa holds that "[c]orruption and maladministration are inconsistent with the rule of law and the fundamental values of our Constitution. They undermine the constitutional commitment to human dignity, the achievement of equality and the advancement of human rights and freedoms." ${ }^{21}$ In a 2012 judgment, the Supreme Court of India held that "[c]orruption [...] undermines human rights, indirectly violating them", and that "systematic corruption is a human rights' violation in itself". ${ }^{22}$ From a legal standpoint, it is crucial whether we qualify a situation as merely undermining human rights, or whether we qualify it as a true rights violation that must be deemed unlawful and may be addressed with the usual sanctions.

\section{What State action? Violations of what obligations?}

For that reason, we have to examine what kinds of obligations are generated by the human rights in question in

Rev.1, second preambular paragraph, italics mine).

20 UN Human Rights Commission, Progress report 2005 (n. 17), para. 41.

21 Constitutional Court of South Africa, South African Association of Personal Injury Lawyers $v$ Health and Others, 28 November 2000, (CCT $27 / 00$ ) [2000] ZACC 22, para. 4. See also ibid., Hugh Glenister v President of the Republic of South Africa and others, 17 March 2011, (CCT 48/10) [2011] ZACC 6, para. 176: "Endemic corruption threatens the injunction that government must be accountable, responsive and open [...]"; para. 177: "It is incontestable that corruption undermines the rights in the Bill of Rights, and imperils democracy".

22 [2012] 9 S.C.R. 601602 State of Maharashtra through CBI, Anti Corruption Branch, Mumbai v. Balakrishna Dattatrya Kumbhar (Criminal Appeal No. 1648 of 2012), 15 October 2012, para. 14. 
order to determine which of them can be violated by corrupt State action.

\section{Three dimensions of obligations}

As is generally known, all types of human rights give rise to three kinds of obligations, namely the obligations to respect, protect, and fulfil human rights. The obligation to respect is essentially a negative obligation to refrain from infringements. The obligation to protect primarily refers to protection from dangers emanating from third parties. The obligation to fulfil requires positive action by the State. The UN Committee on Economic, Social and Cultural Rights divides this obligation in turn into the three subcategories of facilitate, provide, and promote ("fulfil (facilitate) [...] fulfil (provide) [...] fulfil (promote)"). ${ }^{23}$

\section{Obligations of officials and of the State}

We have to distinguish two points of contact in this regard: firstly, the specific corrupt conduct of an individual official that is attributed to the State due to the official's status; and secondly, the general anti-corruption policy of the State as a whole as an international legal person.

A corrupt act by an individual official may, depending on the context and the human right in question, potentially violate each of these dimensions of obligation. If, in the context of the implementation of a land-use plan, an official forcibly evacuates people who do not pay a bribe, then this may violate the right to housing (Article 11 ICESCR) in the negative dimension of the obligation to respect. If, for instance, the employee of a registration office refuses to hand over a passport without an additional bribe, then the right to leave the country (Article 12(2) ICCPR) may be violated in the positive dimension of the State obligation to facilitate.

23 This threefold division was introduced for the first time in Committee on Economic, Social and Cultural Rights (CESCR), General Comment No. 14, The Right to the Highest Attainable Standard of Health (Art. 12) (2000), para. 37.

\section{Obligations of the State to protect}

In the following discussion, I will focus on the macro level, namely the question of how to qualify - from the perspective of these three dimensions of obligation - the lack of effective anti-corruption measures in a State where corruption is rampant. The deficient implementation, application, and enforcement of effective anti-corruption measures essentially constitute an omission by the State. Because human rights give rise to the above-mentioned obligations to become active, omissions may violate human rights. ${ }^{24}$ Effective anti-corruption measures may be considered a way to comply with one of the three facets of the positive obligation to fulfil (facilitate, provide, promote)..$^{25}$

The obligations to protect human rights appear even more relevant, however. In principle, these obligations are addressed to all three branches of government. They obligate the legislative power to enact effective laws, ${ }^{26}$ the executive power to undertake effective administrative measures, and the judicial power to engage in effective legal prosecution.

The case law of the international bodies is not entirely clear in answering the question of whether these obligations to protect - especially the problematic manifestation of a right to have laws amended or the extreme case of an obligation to prosecute 27 - in fact arise from an individual right of the victims of corruption or only from the dimension of the

24 For social human rights, see Maastricht Guidelines on Violations of Economic, Social, and Cultural Rights (1997), Human Rights Quarterly 20 (1998), 691-704, para. 11. See, e.g., for the right to education, CESCR, General Comment No. 13, The Right to Education (Art. 13) (1999), para. 58.

25 See, e.g., Boersma 2012 (n. 4), 244 in regard to the right to housing.

26 Legislative omissions thus in principle also fall under the heading of human rights violations through omission: Para. 15(d) of the Maastricht Guidelines (n. 24) mentions the "failure to regulate activities of individuals or groups so as to prevent them from violating economic, social and cultural rights" (italics mine).

27 See Anne Peters, Jenseits der Menschenrechte (Tübingen: Mohr 2014), 234-245. 
involved human rights under objective law. The case law so far has not unambiguously distinguished obligations of the legislative power to close legal gaps from any corresponding individual rights vis-à-vis the legislative power. ${ }^{28}$

The dimension of the obligation to protect was developed in regard to dangers emanating from third parties, such as economic operators. ${ }^{29}$ The obligation to protect is thus suitable to provide additional human rights support for the criminalization of foreign bribery demanded by the OECD Anti-Bribery Convention. ${ }^{30}$ State obligations to protect in regard to the activities of transnational corporations, grounded in human rights, are set out in the soft law of the United Nations Guiding Principles of Business and Human Rights of 2011 (Ruggie Principles). ${ }^{31}$

28 In the field of social rights, no such distinction was in fact necessary until entry into force of the Optional Protocol of the ICESCR providing for individual communications, because social rights were until then not (quasi-)justiciable (on an individual basis). Under German constitutional law, a right to the enactment of norms or the amendment of laws arises from basic rights only in extreme cases, "when it is evident that an originally lawful rule has become unsustainable under constitutional law in the interim due to changes to the circumstances, and if the legislative power has nonetheless failed to act or has enacted evidently deficient corrective measures" (Federal Constitutional Court of Germany, BVerfGE 56, 54 et seq., 81 (Ruling of 14 January 1981) - Fluglärm, para. 66, translation mine). See also BVerfGE 88, 203 et seq. - Schwangerschaftsabbruch II; BVerfGE 46, 160 et seq. - Schleyer. The same should be true at the international level.

29 For access to health care, see, e.g., CESCR, General Comment No. 14 (n. 23), para. 51: "Violations of the obligation to protect follow from the failure of a State to take all necessary measures to safeguard persons within their jurisdiction from infringements of the right to health by third parties. This category includes such omissions as the failure to regulate the activities of individuals, groups or corporations so as to prevent them from violating the right to health of others; [...]" (italics mine).

30 Foreign bribery is the bribery of foreign public officials by a company subject to the jurisdiction of a State party (Articles 1 and 4 of the OECD Anti-Bribery Convention of 1997 (n. 5)).

31 UN Guiding Principles on Human Rights and Transnational Corporations and Other Business Enterprises (UN Doc. A/HRC/17/31), 21 March
The obligation to protect under human rights law does not require the State only to protect from the acts of private persons, but also to reduce structural human rights risks in which the State's own officials are involved. ${ }^{32}$ For instance, in the case of police violence contrary to human rights, the European Court of Human Rights demands that the State investigate and prosecute after such incidents. ${ }^{33}$

If we accept that rampant corruption constitutes a permanent structural danger to numerous human rights of the persons de facto subject to the power of officials, then - in cases involving the complete inaction of the State or evidently deficient anti-corruption measures - the State is in any event responsible under international law for its failure to fulfil its human rights obligations to prevent and protect. ${ }^{34}$

These human rights obligations would significantly strengthen the preventive obligations specifically under anti-corruption law. Chapter II of the UN Convention against Corruption requires the States parties to adopt a series of preventive measures, ranging from the establishment of an anti-corruption body and the reorganization of public service to

2011; adopted by the UN Human Rights Council on 6 July 2011 (UN Doc. A/HRC/RES/17/4).

32 See Franz Christian Ebert/Romina I Sijniensky, Preventing Violations of the Right to Life in the European and the Inter-American Human Rights Systems: From the Osman Test to a Coherent Doctrine on Risk Prevention? Human Rights Law Review (2015), 343-368.

33 ECtHR, 27 September 1995, McCann and Others v. UK, No. 18984/91, paras. 157 et seq.; ECtHR, 9 April 2009, Silih v. Slovenia, No. $71463 / 01$, paras. 192 et seq. Obligation to institute criminal proceedings: ECtHR, 15 December 2009, Maiorano and Others v. Italy, No. 28634/06, para. 128.

34 Constitutional Court of South Africa, Glenister (n. 21), para. 177: "The state's obligation to 'respect, protect, promote and fulfil' the rights in the Bill of Rights thus inevitably, in the modern state, creates a duty to create efficient anti-corruption mechanisms". In the literature, see Magdalena Sepúlveda Carmona/Julio Bacio Terracino, Corruption and Human Rights: Making the Connection, in: Martine Boersma/Hans Nelen (eds.), Corruption and Human Rights: Interdisciplinary Perspectives (Antwerp: Intersentia 2010), 27. 
the enactment of codes of conduct for public officials, the reorganization of public procurement, and the prevention of money laundering. From the perspective of general international law, these are obligations to prevent. Because the formulation of the UNCAC obligations is rather soft, it is hardly possible to hold a State party internationally responsible if it fails to fulfil its obligations or does so only poorly. But if we interpret them in conformity with human rights law (Article 31(3)(c) of the Vienna Convention on the Law of Treaties), it becomes apparent that the measures mentioned here must in fact be taken in an effective way in order to fulfil the obligations to protect and to fulfil (including to prevent) grounded in human rights law. ${ }^{35}$

\section{Procedural obligations}

Cutting across the three dimensions of human rights obligations, procedural obligations arise from all the types of human rights. In the case law of the ECtHR, these constitute the "procedural limb" of the rights under the ECHR. Within the scope of social human rights, they are referred to as "process requirements". ${ }^{36}$ Here, one of their functions is to serve as an indicator for the fulfilment of the progressive obligation to implement, which is very difficult to measure. Procedural elements are also central to combating corruption. The human rights process requirements relevant here most likely include planning obligations ${ }^{37}$ and monitoring obli-

35 See ECOWAS Court, Judgement of 14 December 2012, Socio-Economic Rights and Accountability Project (SERAP) v Federal Republic of Nigeria, para. 32: "the [...] obligation required from the State to satisfy such rights is the exercise of its authority to prevent powerful entities from precluding the most vulnerable from enjoying the right granted to them" (italics mine). At issue in this judgment was the violation of social human rights by oil prospecting companies.

36 See Philipp Alston/Gerard Quinn, The Nature and Scope of State Parties' Obligations under the International Covenant on Economic, Social and Cultural Rights, Human Rights Quarterly 9 (1987), 156-229, 180 (regarding the determination of whether "the maximum of available resources" was used).

37 See CESCR, General Comment No. 1, Reporting by States Parties (1989), para. 4; Constitutional Court of South Africa, Government of the gations. ${ }^{38}$ Transparency obligations are especially important. Not coincidentally, the best-known anti-corruption NGO in the world is called "Transparency International". Transparency is also a fundamental principle of the UNCAC (2003). ${ }^{39}$

Accordingly, the procedural obligations under UNCAC, especially the disclosure and publication requirements, which can be an effective way to curtail corruption, are equally grounded in human rights. ${ }^{40}$ Viewed in that light, failure to satisfy these obligations simultaneously constitutes a violation of the relevant human rights.

\section{Result-independent obligations}

A follow-up question is whether a corrupt State violates its obligations of protection and its procedural obligations only when and if individual acts of corruption are (or continue to be) in fact committed. In the context of the international obligations to prevent, it depends in principle on the specific primary obligation whether "prevent" means that a State must in fact avert the undesirable result, or whether the State is merely obligated to employ all reasonable and appropriate means in the sense of a due diligence obligation that is independent of the result. ${ }^{41}$

Republic of South Africa and Others v Grootboom and Others (CCT11/00) [2000] ZACC 19; 2001 (1) SA 46; 2000 (11) BCLR 1169 (4 October 2000), paras. 39 et seq. on a "co-ordinated state housing programme". 38 See CESCR, General Comment No. 3, The Nature of States Parties' Obligations (Art. 2, Para.1) (1990), para. 11; Maastricht Guidelines (n. 24), para. 15(f).

39 See, e.g., Articles 5, 7, 9, 10, 12, 13 UNCAC (n. 5). See also OECD Guidelines for Multinational Enterprises (2011), Section VII: Combating Bribery, Bribe Solicitation and Extortion, para. 5: "Enhance the transparency of their activities in the fight against bribery, bribe solicitation and extortion".

40 See, e.g., CESCR, General Comment No. 12, The Right to Adequate Food (Art. 11) (1999), para. 23 on transparency as a guiding principle for the formulation and implementation of national strategies for the right to food.

41 See James Crawford, State Responsibility: The General Part (Cambridge 2013), 227. 
The anti-corruption obligations under human rights law mentioned above should be interpreted in a result-independent manner. This establishes a doctrinal parallelism to the consideration under criminal law. Bribery and other offences that we summarize under the umbrella of corruption are, generally speaking, "endangerment offences". This means that they criminalize conduct which endanger legally protected interests even if that conduct does not produce a specific harmful consequence. This is appropriate to the legally protected interest which is the integrity of the public service, because it is usually impossible to determine whether a tangible harm has in fact occurred. If the bribing of a public official does not entail that the briber is granted a doctor's appointment faster than without the bribe, or if the briber does not receive a building permit exceeding the official's normal discretion, then the bribes would, in a non-technical sense, be "unsuccessful". Nevertheless, the trust in the public service has been undermined, and for that reason the unlawful agreement should be punished as bribery. In the courts, this rationale is referred to as follows: "Justice should not only be done, but should manifestly and undoubtedly be seen to be done." 42 The situation here is different than in the case of the obligation to prevent genocide, for example. In that case, the ICJ held that "a State can be held responsible for breaching the obligation to prevent genocide only if genocide was actually committed". ${ }^{43}$ This difference in assessment is justified because genocide is a result offence in terms of criminal law, as opposed to an endangerment offence.

Conversely, the obligation (also under human rights law) to combat corruption, as follows for instance from the UNCAC, does not require States to stop corruption entirely. The satisfaction of such a "negative" obligation of result (and the

42 Lord Hewart CJ, The King v. Sussex Justices, ex parte McCarthy, 9 November 1923, 1 King's Bench Division, 256-260 (259); cited without source in ECtHR, 17 January 1970, Delcourt v. Belgium, No. 2689/65, para. 31 .

43 ICJ, Application of the Convention on the Prevention and Punishment of the Crime of Genocide (Bosnia and Herzegovina v. Serbia and Montenegro), Judgment of 26 February 2007, para. 431. measurement of such a result) would be impossible, given that the realization of a low level of systematic corruption is not a one-time success. It is, in contrast, easy to determine that a genocide, for instance, has not been commited.

Consequently, this means that the State already violates its preventive and other procedural obligations under both anti-corruption law and human rights law if it fails to act, even if the level of corruption is low despite the laxity of the State. Conversely, a State is released from international responsibility if it takes reasonable protective measures, even if the State is not entirely "clean".

\section{Corruption as a violation of the fundamental obligations set out in Article 2(1) ICESCR}

Under certain circumstances, corruption (both petty and grand) must notably be considered a violation of the International Covenant on Economic, Social and Cultural Rights. As mentioned above, corruption - for example in the police force and the judiciary - also affects human rights enshrined in the ICCPR. But this section concentrates on the ICESCR because the legal analysis of the violation of this Covenant is particularly challenging in analytic terms.

Article 2(1) ICESCR, which sets out the fundamental obligations of the States parties, contains four components that are subject to monitoring by the treaty body, the CESCR. ${ }^{44}$ Each component is a starting point for specific State obligations, including in the field of anti-corruption. Each of these obligations may become difficult or impossible to fulfil in the

44 On the operationalization of these elements, see Limburg Principles on the Implementation of the International Covenant on Economic, Social, and Cultural Rights (1986), Human Rights Quarterly 9 (1987), 122-135; Maastricht Guidelines on Violations of Economic, Social, and Cultural Rights (1997), Human Rights Quarterly 20 (1998), 691-704; CESCR, General Comment No. 3, The Nature of States Parties' Obligations (Art. 2, Para. 1) (1990). 
circumstances of grand or petty corruption.

The first element - the core obligation - is "to take steps". These steps, according to the CESCR, must be "deliberate, concrete and targeted". ${ }^{45}$ It is easy to see that the steps to be taken must include the elimination of obstacles to the realization of economic, social, and cultural rights. Because corruption constitutes such an obstacle, States are in principle required by the ICESCR to take anti-corruption measures. ${ }^{46}$ The Inter-American Commission on Human Rights, for instance, in its guidelines for national reporting, considers ratification of the Inter-American Convention against Corruption and the existence, powers, and budget of a domestic anti-corruption authority to be structural indicators for national progress reports. ${ }^{47}$

The second component of the implementation obligation set out in Article 2 of the ICESCR is that the State party must take these steps "with a view to achieving progressively the full realization of the rights recognized in the present Covenant". This component obligates parties to grant a certain priority in the allocation of resources to the realization of human rights. ${ }^{48}$ The misappropriation of public funds at the highest level violates this obligation, because in such cases the financing of the standard of living of high-level public officials is given priority over the realization of social human rights. ${ }^{49}$

The third element is to exhaust all possibilities the State has at its disposal ("to the maximum of its available resources").

45 CESCR, General Comment No. 3 (n. 44), para. 2.

46 See Boersma 2012 (n. 4), 229-230.

47 Inter-American Commission on Human Rights, Guidelines for Preparation of Progress Indicators in the Area of Economic, Social, and Cultural Rights (OEA/Ser.L/V/II.132, Doc. 14 of 19 July 2008), 24.

48 See Limburg Principles (n. 44), para. 28; CESCR, General Comment No. 12 (n. 40), paras. 17 and 14 (n. 29), para. 47. In the literature, see Magdalena Sepúlveda, The Nature of the Obligations under the International Covenant on Economic, Social and Cultural Rights (Antwerp: Intersentia 2003), 332-335.

49 See Boersma 2012 (n. 4), 233.
Primarily, the State party itself defines which resources are available and what the maximum is. ${ }^{50}$ However, according to the Limburg Principles, the CESCR may consider the "equitable and effective use of [...] the available resources" when determining whether the State party has taken appropriate measures. ${ }^{51}$ The component likewise gives rise to a prohibition against the diversion of resources that were originally dedicated to social purposes..$^{52}$ In their concluding observations on individual States, the various human rights treaty bodies regularly refer to the importance of anti-corruption measures in precisely this context. ${ }^{53}$

In fact, grand corruption deprives the State of resources in an "inequitable" way. This is evident when funds are directly misappropriated from the government budget. This also occurs in the case of excessive infrastructure projects or "white elephants" and the exaggerated purchase of military equipment. When developing buildings, roads, airports, etc., of an inferior quality, the funds intended for construction materials can easily be diverted by high-level employees of the government purchasers. Petty corruption likewise indirectly deprives the State of resources, in that it reduces tax compliance. The affected persons do not see why they should have to pay the government twice - once through taxes, and once directly to corrupt public officials. Even an extremely inflated budget appropriation for the government's public relations work may already be inequitable if the members of parliament approving the budget know that the budget item is being used to divert funds, typically by way of accepting inflated invoices from consulting companies paid by government agencies, whereupon the consultants transfer the

50 See Ben Saul/David Kinley/Jacqueline Mowbray, The International Covenant on Economic, Social and Cultural Rights: Commentary, Cases, and Materials (Oxford: OUP 2014), 143.

51 See Limburg Principles 1986 (n. 44), para. 27.

52 See Sepúlveda Carmona (n. 48), 315.

53 See, e.g., Committee on the Rights of the Child, Concluding observations on the combined third and fourth periodic reports of Morocco, CRC/C/MAR/CO/3-4 of 14 October 2014, para. 17; Concluding observations on the combined third and fourth periodic reports of Croatia, CRC/C/HRV/CO/3-4 of 13 October 2014, para. 13. 
money back to the private accounts of the ministry officials (kickbacks). It must be decided from case to case when the obligation to use all available resources as set out in Article 2(1) ICESCR has been violated.

The fourth component of the fundamental obligation set out in the ICESCR is to employ "all appropriate means", which I will come back to below. Whenever the State party fails to comply with any of these obligations, ${ }^{54}$ it is in non-compliance with the Covenant. In the final analysis, the Social Rights Committee could, lege artis and as a way of continuing its own practice and that of the States parties, use the existing monitoring procedures to make the authoritative determination that a State with rampant corruption is violating its fundamental obligation arising from the ICESCR by pursuing an evidently deficient anti-corruption policy.

\section{Causation of the human rights violation}

A key doctrinal problem for determining a human rights violation through corrupt conduct is causation. This is true both for omissions by the State as a whole as well as for the corrupt acts of individual public officials that occur concomitantly.

\section{International legal principles}

The determination of legal causation is based on the principles of the law of State responsibility. ${ }^{55}$ Unless special rules exist, these principles apply to State responsibility arising from violations of human rights. ${ }^{56}$ There are no uniform

54 The difficult question of how precisely the CESCR makes this determination cannot be discussed here in detail.

55 See Léon Castellanos-Jankiewicz, Causation and International State Responsibility, SHARES Research paper 07 (2012) ACIL 2012-07; Crawford (n. 41), 492-503.

56 See Article 33(2) and Article 55 of the ILC Articles on State Responsibility (UNGA res. 56/83 of 12 December 2000). rules of causation under international law. ${ }^{57}$ The Articles on State Responsibility of the International Law Commission are silent in regard to the causal link between the conduct and the legal breach. ${ }^{58}$ But at least the provision in Article 31 of the ILC Articles governs the causal link between the legal breach and the damage.

There is also State practice in regard to the causal link between the legal breach and the damage in the area of human rights violations ${ }^{59}$ and for war damages. In this regard, it is recognized that causation (in the sense of a conditio sine qua non or "necessity") must be supplemented by an evaluative element that "in legal contemplation" cuts off chains of causation that are excessively long. ${ }^{60}$ There must

57 See Eritrea-Ethiopia Claims Commission (EECC), Decision No. 7: Guidance Regarding Jus ad Bellum Liability, 27 July 2007, paras. 8-9.

58 In international legal terminology, this concerns the "breach of an international obligation of the State"; Article 2(b) of the ILC Articles (n. 56).

59 On the causal link between the legal breach and the damage in regard to the recognition of "just satisfaction" in accordance with Article 41 of the European Convention on Human Rights (ECHR), see ECtHR, Case of Chevrol v. France, No. 49636/99, 13 February 2003, paras. 86-89; Case of Sylvester v. Austria, No. 36812/97 and 40104/98, 24 April 2003, paras. 79-92 (especially 81-84, 91); Case of Nowicka v. Poland, No. 30218/96, 3 December 2002, paras. 79-83, especially 82. In these cases, the ECtHR denied a sufficient causal link between the identified human rights violations and the claimed pecuniary loss, e.g., loss of income due to non-recognition of a diploma (Chevrol), loss of job due to travel undertaken to visit a child that had been kidnapped in violation of the right to family life (Sylvester); compensation of excessively long imprisonment in violation of Article 4 ECHR (Nowicka). However, the requirements for such causation were not examined in any detail.

60 US-German Mixed Claims Commission, Administrative decision No. II, 1 November 1923, RIAA vol. VII, 23-32, 29. The arbitral tribunal continued: "It matters not whether the loss be directly or indirectly sustained so long as there is a clear, unbroken connection between Germany's act and the loss complained of. It matters not how many links there may be in the chain of causation connecting Germany's act with the loss sustained, provided there is no break in the chain and the loss can be clearly, unmistakably, and definitely traced, link by link, to Germany's act. [...] All indirect losses are covered, provided only that in legal contemplation 
be "proximity" ${ }^{61}$ between the legal breach and the injury. Only for damage/losses that are "not too remote" 62 is reparation owed. ${ }^{63}$ "Proximity" is determined on the basis of the objective criteria of "natural and normal consequence" 64 and the subjective criterion of "foreseeability" ${ }^{65}$

Applied to our effort to determine the causal link between the corrupt act and the legal breach, these terms convey the idea that corrupt acts (or omissions) cause human rights violations in the legal sense only if the violations - such as of the right to food, housing, or education - are foreseeable and not too far removed from the corrupt public officials (or the otherwise passive apparatus of the State). In many cases, these requirements are likely to be met. For instance, an arrangement for a court official to receive a small sum of money to summon a witness is causally related to the violation of the right to a fair trial. Similarly, bribes paid to the employee of an environmental supervisory authority, intended to induce the employee to "overlook" the creation of an

Germany's act was the efficient and proximate cause and source from which they flowed", (ibid. 29-30, italics mine). See also Arbitral Tribunal, Provident Mutual Life Insurance Company and others (United States) v. Germany, 18 September 1924, RIAA vol. VII (1924), 91-116, 112-113.

61 EECC Dec. No. 7 (n. 57), para. 13.

62 ILC Commentary, Article 31, para. 10 (ILC YB 2001/II vol. 2, Doc. $A / 56 / 10$, Report of the International Law Commission on the work of its fifty-third session (23 April-1 June and 2 July-10 August 2001), Part E: Draft Articles on Responsibility of States for Internationally Wrongful Acts, 93).

63 See Arbitral Tribunal, Trail Smelter Case, United States v. Canada RIAA 3 (16 April 1938 and 11 March 1941), p. 1905 et seq. (p. 1931): Damage that is "too indirect, remote, and uncertain" is not liable for compensation.

64 Provident Mutual Life Insurance Company (n. 60), 113.

65 EECC decision No. 7 (n. 57), para. 13. See already the Naulilaa case: Responsabilité de l'Allemagne à raison des dommages causés dans les colonies portugaises du sud de l'Afrique (sentence sur le principe de la responsabilité) (Portugal v. Germany), 31 July 1928, RIAA vol. II, 10111033 (1031). Para. 14 of EECC decision No. 7 (n. 57) points out that the choice of a verbal formula to describe the necessary degree of connection does not necessarily result in a difference in outcomes. illegal toxic waste dump is, according to these principles, still considered to be a cause of the subsequent adverse health effects of the local residents. In such cases, the approval of the toxic waste dump and the damage to health were foreseeable for the public official and were in the usual course of things. The corrupt toleration of the toxic waste dump is thus in the eyes of the law a cause of the violation of the human rights of the local residents in terms of respect for their private life and physical integrity. ${ }^{66}$

\section{Special problems of causation}

Conversely, a legal causal link should not be affirmed where corruption, where any subsequent human rights violation is not in the usual course of things and is not foreseeable. As an example: Assume that election bribery leads to riots after announcement of the election results, i.e., protests that in turn are struck down by excessive force by the police. The violation of the freedom of assembly and bodily integrity of the demonstrators has then - in legal terms - not been caused by the electoral corruption. ${ }^{67}$

In addition to the situation where the "distance" between the cause and the human rights violation is too great - which is especially frequent in the context of grand corruption - other special problems of causation arise. A common situation occurs when the human rights violation has several causes, the precise share of which cannot be determined, and only one of which is corruption (alternative causation). As an example, assume that school children are killed by the falling debris of a collapsing school during an earthquake. After the incident, it is determined that the school was built with deficient materials because construction materials had been diverted by municipal officials for their own use and the building inspector had been bribed. But it can no longer be determined after the fact whether the school would have

66 See Sepúlveda Carmona, in: International Council on Human Rights Policy (n. 4), 27 refers to this constellation as an "indirect link" between corruption and human rights violations.

67 See Sepúlveda Carmona/Bacio Terracino, in: Boersma/Nelen (n. 34), 30 . 
collapsed even if it had been constructed properly. In such a case of alternative causation, corruption is still seen as a legal cause according to general legal principles - such as the European Tort Law Principles. ${ }^{68}$ The further question of whether the causal link is close enough to attribute the deaths to the corrupt building supervisor must be examined in detail, however, and may in some cases be denied.

Moreover, human rights violations are often due to competing causes, each of which would be sufficient. Corruption may only be one of several. Other factors, such as resource allocation without prioritization of social human rights, would be sufficient to trigger the human rights violation in a legal sense. In that case, corruption would not be a conditio sine qua non or a "necessary condition" of the particular human rights violation.

One variant, when looking at the situation over a period of time, is referred to as "overtaking" causation. As an example, assume that the judge is bribed by a party to a civil trial in order to prolong the proceedings. But because the courts have insufficient human and financial resources anyway, the trial would have been delayed substantially even without this corrupt act, and that delay in itself would have violated the right of a party to a trial without undue delay. According to international case law, such competing causes do not mean that the bribery may not be considered to be the legal cause of the human rights violation. ${ }^{69}$

68 See Art. 3:103, Alternative causes, in Chapter 3, Causation (Art. 3:101 106), of the Principles of European Tort Law, European Group on Tort Law, Text and Commentary (Vienna and New York: Springer 2005).

69 However, case law exists only in regard to the causal link needed to identify damage ("haftungsausfüllende" causality), not in regard to the causal link between behaviour and legal breach ("haftungsbegründende" causality): See EECC, Final Award: Ethiopia's Damages Claims, 17 August 2009, RIAA XXVI, 631-770, 733 (para. 330): People left their places of residence in part because of the drought and in part because of the war, although the war was the main cause. The Claims Commission entirely disregarded the potential additional cause (the drought) for determining the number of internally displaced persons, which in turn was used to calculate compensation. See also the Tehran hostage case, which at

\section{Causation in the case of omission}

Finally, the relevant human rights violations linked to corruption often consist in the non-performance of obligations of protection and procedural obligations. This gives rise to the question of causation in the case of omission. Normally, legal causation in the case of omission is affirmed if the legally required positive action would, with near certainty, have eliminated the (undesirable) result. (This is a softened "but for"-test). When it comes to omitting mere obligations of conduct, however, this "but for"-test does not make any sense and cannot be applied, because these obligations do not require from the state to reach a particular result (see above).

In the Bosnian Genocide case, the International Court of Justice found that an obligation of prevention exists even if the State cannot be certain whether the preventive measures will be successful or not. ${ }^{70}$ This means that the State cannot avoid responsibility simply by showing that genocide (or in our case, corruption) would have taken place despite all its efforts to prevent it. So although proper preventive action would not have eliminated the problem, the omission to act properly still counts as a legal cause. If causation were denied here, the State would be able to avoid responsibility too easily. Even if the failure to act thus did not cause the undesirable result in a scientific sense (because the result would have occurred anyway), causality is nevertheless

the same time illustrates the situation where it cannot be determined after the fact which cause led when and how precisely to the breach of international law: A private attack against the embassy took place, but at the same time Iran failed to protect the embassy. The ICJ held Iran fully responsible and did not reduce the liability of the State on account of any non-attributable contribution to the breach of international law by the private students (ICJ, United States Diplomatic and Consular Staff in Tehran, ICJ Reports 1980, 3 et seq., paras. 76-77 and 90).

70 In that case, success would have been the prevention of genocide. See ICJ, Application of the Convention on the Prevention and Punishment of the Crime of Genocide (Bosnia and Herzegovina v. Serbia and Montenegro), Judgement of 26 February 2007, para. 461. 
affirmed in a legal sense. ${ }^{71}$ According to this analysis - which is common in the law of torts and criminal law - a State can be held legally responsible for a high level of corruption even if no causal link can be established between its omission of particular policies (e.g., establishment of an anti-corruption authority with extensive powers and generous financial resources) and particular corruption scandals. It should therefore be considered additionally whether a mere statistical correlation of corruption indicators and human rights non-compliance indicators might be sufficient to affirm a violation of these human rights "by" the omission of anti-corruption efforts of the State - analogously to the purely statistical evidence that is commonly used to show indirect discrimination.

\section{Attribution to the State}

The next doctrinal problem is how to attribute corrupt conduct to the State. According to Article 4 of the ILC Articles on State Responsibility, the conduct of any State organ is attributable to the State itself. This has been unproblematic so far in regard to the omissions primarily discussed above, which violate obligations of prevention and protection under human rights law. Such omissions concern the legislative, executive, and judicial organs of the State that fail to fulfil the obligations addressed directly to them.

\section{Attribution of corrupt individual acts}

The analysis is different in the case of particular individual acts of public officials, especially in the area of petty corruption. Can these be attributed to the State as a whole, so that they trigger State responsibility for the resulting human

71 In the Genocide case, however, the ICJ considered in regard to the causal nexus between the breach and the content of the state responsibility ("haftungsausfüllende" causality, i.e. in order to determine whether Serbia owed reparations) whether genocide would have occurred even despite efforts to prevent it (ibid., para. 462). Because this could not be shown, the ICJ did not believe financial compensation by Serbia to be appropriate. rights violations? Corrupt public officials obviously exceed their formal authority. Under the norms of State responsibility, however, ultra vires acts are in principle also attributed to the State. The precondition is that an organ of the State or a person empowered to exercise governmental authority acts "in that capacity" (Article 7 of the ILC Articles). Such conduct in an official capacity must be distinguished from private conduct. $^{72}$

The landmark cases in international law that examine this distinction do in fact concern corrupt acts of public officials. According to this case law, it matters whether the official acted "under cover" of public office and also made use of the special (coercive) powers of the office (such as the power to search or arrest individuals). ${ }^{73}$ According to

72 See Crawford (n. 41), 136-140

73 The locus classicus is French-Mexican Claims Commission, Estate of Jean-Baptiste Caire (France) v. United Mexican States, RIAA 5 (7 June 1929), 516-534: Caire, a French citizen, ran a boarding house in Cairo. A French major of the troops stationed there and two soldiers tried to extort money from Caire under threat of force. When Caire refused, the major and a captain of the same brigade arrested Caire, searched him, drove him to another village, and shot him dead. The arbitral tribunal considered this conduct to be an official act attributable to the State. Responsibility was justified "lorsque ces organes agissent en dehors de leur compétence, en se couvrant de leur qualité d'organes de l'Etat, et en se servant des moyens mis, à ce titre, à leur disposition” (530). See also Iran-US Claims Tribunal, Yeager v. Iran, Case No. 10199, Award No. 324-10199-1, 2 November 1987, Claims Tribunal Reports (CTR) 17 (1987), 92-113. At issue here was a claim against Iran alleging a corrupt act by an employee of the State airline Iran Air. The claimant was forced by the airline in an unlawful way to make an "extra payment" for a plane ticket. The tribunal did not attribute this corrupt act of the State employee to Iran: "Acts which an organ commits in a purely private capacity, even if it has used the means placed at its disposal by the State for the exercise of its functions, are not attributable to the State. [...] There is no indication in this case that the Iran Air agent was acting for any other reason than personal profit, or that he had passed on the payment to Iran Air. He evidently did not act on behalf or in the interests of Iran Air. The Tribunal finds, therefore, that this agent acted in a private capacity and not in his official capacity as an organ for Iran Air" (111, 
the ILC Commentary, it matters whether the corrupt person was purportedly acting in an official capacity and with "apparent authority". ${ }^{74}$

Applying these principles to our question, we see that as a rule, the corrupt official acts under cover of and with apparent public authority. The official uses his or her position to perform or omit a measure that the official would be unable to do as a private person, such as granting an authorization or licence, refraining from public prosecution, or imposing a fine. As a rule, corrupt conduct by public officials should therefore be attributed to the State in accordance with the principles of State responsibility.

\section{Attribution in light of the rationale of outlawing corrup- tion}

But should not, from a normative perspective, attribution be further limited in light of the rationale of outlawing corruption? Does the proscription against corrupt official acts (or the improvement of State anti-corruption measures) correspond at all to the object and purpose of human rights? Only then would it be legally appropriate to classify corrupt State conduct not only as a governance deficit and, under certain circumstances, as a criminal offence under domestic law, but simultaneously and additionally as a human rights violation.

At first glance, the criminal law on corruption and human rights law serve different objectives. The objective of the criminalization of bribery in German criminal law, for instance, is to "protect the functioning of the public administration

para. 65). This finding is defensible, but the reasoning is not persuasive. Rather, it was significant that the employee did not pretend to be demanding the extra payment on behalf of the State (see also Crawford 2013 (n. 41), 138).

74 ILC Commentary on Article 7, para. 8: "[...] purportedly carrying out their official functions [...] the question is whether [the individuals] were acting with apparent authority" (ILC YB 2001/II vol. 2, Doc. A/56/10, Report of the International Law Commission on the work of its fifty-third session (23 April-1 June and 2 July-10 August 2001), Part E: Draft Articles on Responsibility of States for Internationally Wrongful Acts, 46). and public trust in the objectiveness and independence of administrative conduct". ${ }^{75}$ The goal is therefore "to protect the institution of public service and thus a fundamentally important public good". ${ }^{76}$ In this light, can corruption be considered an attack against human rights - the individual legally protected good par excellence? My answer is yes, because of course the interests of the individual are what underlie the State and the public service protected by the criminalization of bribery. The criminal law on corruption is about "protecting trust in the interest of the individual citizen". ${ }^{77}$ Protection of "the public" and protection of the human rights of all persons in a given State are therefore not opposites or different categories. The public interest in the legitimacy of the State is also what underlies human rights protection. The modern liberal State is legitimate only in that and to the extent that it protects human rights.

The remaining difference is that corruption is a conduct offence, while human rights violations can be found only if a concrete injury actually occurs. ${ }^{78}$ But this important structural difference does not prevent attribution a priori; it only means that not every corrupt act also constitutes a human rights violation. If, for example, gifts presented by a pharmaceutical company to a minister of health do not ultimately succeed in modifying the ministry's patterns of purchase and of the distribution of vaccines in urban slums, this may very well be considered bribery, but the rights of the slum residents to physical integrity or health care have not been violated, because the bribery did not have an impact

75 Matthias Korte, § 331, para. 8, in: Wolfgang Joecks/Klaus Miebach (eds.), Münchener Kommentar zum StGB, 2nd ed. Munich 2014 (translation mine).

76 Ibid., para. 12.

77 Günter Heine and Jörg Eisele in Strafgesetzbuch: Kommentar (29th ed. Munich: Beck 2014), § 331, para. 9.

78 This difference is narrowed in that according to the case law of the ECtHR, a concrete future rights violation may under certain circumstances already establish standing as a victim and make an individual claim admissible; see, e.g., ECtHR, 29 October 1992, Open Door and Dublin Well Woman v. Ireland, No. 14234/88 and others, para. 44 on women of childbearing age as "victims" of a prohibition of abortion. 
on their standard of care.

In the final analysis, the proscription against corruption fits the protective purpose of human rights; on the basis of these fundamental considerations, the attributive relationship between corrupt acts or omissions and human rights violations does not have to be denied.

\section{Special aspects of determining a violation of the prohibitions of discrimination}

Then UN Secretary-General Kofi Annan wrote in the foreword to the UN Convention against Corruption that corruption "hurts the poor disproportionately" and promotes "inequality". ${ }^{79}$ This finding can be expressed in the language of anti-discrimination law. Corruption might potentially violate the prohibitions against discrimination found in the universal and regional human rights conventions. ${ }^{80}$

I see three doctrinal obstacles, but they are not insurmountable. The UN covenants contain ancillary prohibitions against discrimination that apply only in connection with the exercise or enjoyment of a right under the covenants. ${ }^{81}$ The ICCPR also contains the autonomous equal treatment guarantee set out in Article 26, which is relevant to discrimination in the area of social rights as well as to the economic rights of competitors in public procurement (due to the lack of a guarantee of property and economic freedom in the covenant). However, firstly, discrimination comes into play only if it involves unequal treatment on the basis of a suspect classification. Both human rights covenants prohibit discrimination on the basis of "other status". The lack of ability or

79 UN Secretary-General Kofi Annan, Foreword UNCAC (2003).

80 Along these lines, albeit without a detailed explanation, see C. Raj Kumar, Corruption and Human Rights in India: Comparative Perspectives on Transparency and Good Governance (Oxford OUP 2011), 36, 46-47.

81 Article 2(2) ICESCR and Article 2(1) ICCPR, in conjunction with a right under the covenants. willingness to pay a bribe might be considered an "other status". In its general comment on non-discrimination, the CESCR held that individuals and groups must not be "arbitrarily treated on account of belonging to a certain economic or social group", thus recognizing the inability of a person to pay as a criterion especially worthy of protection. ${ }^{82}$

Secondly, discrimination may not consist only in the targeted unequal treatment of individuals and groups of individuals. Intent by the State to discriminate is not required. In particular, all human rights conventions also protect from indirect discrimination. Indirect discrimination may arise from a State policy that appears neutral, but in reality disproportionately affects certain population groups in a negative way. ${ }^{83}$ Thirdly, discrimination may also arise from an omission, ${ }^{84}$ which is

82 CESCR, General Comment No. 20, Non-discrimination in economic, social and cultural rights (art. 2, para. 2, of the International Covenant on Economic, Social and Cultural Rights) (2009), para. 35: “Individuals and groups of individuals must not be arbitrarily treated on account of belonging to a certain economic or social group or strata within society. A person's social and economic situation when living in poverty or being homeless may result in pervasive discrimination, stigmatization and negative stereotyping which can lead to the refusal of, or unequal access to, the same quality of education and health care as others, as well as the denial of or unequal access to public places" (italics mine).

83 In regard to the ICESCR, which is especially relevant to our discussion, see CESCR, General Comment No. 20 (n. 82), para. 8: "guarantee" means that "discrimination must be eliminated both formally and substantively. [...] States parties must therefore immediately adopt the necessary measures to prevent, diminish and eliminate the conditions and attitudes which cause or perpetuate substantive or de facto discrimination". In regard to the right to education, see CESCR, General Comment No. 13, The Right to Education (Art. 13) (1999), para. 59: The failure to take measures which address de facto educational discrimination violates Article 13. In regard to the right to health, see CESCR, General Comment No. 14, The Right to the Highest Attainable Standard of Health (Art. 12) (2000), para. 50: Denial of access to health services as a result of de facto discrimination of particular groups violates the right to health.

84 For the prohibition of discrimination set out in the ICESCR, see CESCR, General Comment No. 20 (n. 82), para. 14. 
sometimes referred to as "passive discrimination". Prohibitions of discrimination do not require that all individuals be treated identically, but differential treatment must have a legal basis, pursue a legitimate aim, and be proportional. ${ }^{85}$

If an individual is unable or unwilling to pay a bribe in order to pass a police checkpoint or to receive a passport, and is thus unable to continue a journey or exit the country, and if the State does not take any measures to combat this corrupt conduct, then the failure of the State to act has a disproportionate negative impact on individuals without means. It is then not only the affected persons' civil liberties which are curtailed. For lack of a legal basis and a legitimate purpose of the request for payment, these persons are also being discriminated against in conjunction with their right to move freely or exit the country.

\section{Weak anti-corruption measures as an inherent limitation or a legal restriction of human rights covered by the margin of appreciation?}

Even if we regard a particular corrupt act or the general failure to implement anti-corruption measures as a cause of particular human rights violations and attribute it to a State, this does not in any way mean that everything affecting human rights also constitutes a violation thereof. Both legal and political rights and social human rights can be lawfully restricted.

In regard to social human rights, it may even make more sense not to view lesser fulfilment of the progressive implementation obligation as a "restriction" of rights, but rather to view it as an inherent limit to the scope of positive rights. A component of the fundamental treaty obligation set out in Article 2(1) ICESCR (see above) is the use of "all

85 See ibid., para. 13. appropriate means". The obligation to use all appropriate means is further specified by the Optional Protocol to the ICESCR in terms of "reasonableness" (Article 8(4) of the Optional Protocol). ${ }^{86}$

On the one hand, these qualifications constitute a built-in limitation on State obligations. They must be fulfilled only in a "reasonable" way. Social rights do not impose any "absolute or unqualified" obligations upon States, according to the Constitutional Court of South Africa in the landmark Grootboom case. ${ }^{87}$ In the formulation of the Federal Constitutional Court of Germany in regard to social participation rights, social rights are a priori only "subject to what is possible". ${ }^{88}$

On the other hand, the terms "appropriate" and "reasonable" also represent an opening for defining the bottom-line of

86 Article 8(4) of the Optional Protocol to the ICESCR reads: "When examining communications under the present Protocol, the Committee shall consider the reasonableness of the steps taken by the State Party in accordance with part II of the Covenant. In doing so, the Committee shall bear in mind that the State Party may adopt a range of possible policy measures for the implementation of the rights set forth in the Covenant" (italics mine). In the treaty negotiations on the Optional Protocol, there was an important controversy on the level of detail of the CESCR's review and the scope of discretion of the States parties. The proposed terms "margin of appreciation" and "discretion" were ultimately rejected and were not included in the text of the Optional Protocol (see Brian Griffey, The Reasonableness Test: Assessing Violations of State Obligations under the Optional Protocol to the ICESCR, Human Rights Law Review 11 (2011), 275-327, at 295 and 298-300). In the terminology of fundamental rights scrutiny which has been developed for liberal negative rights in Germany, this "built-in" limit to the State's obligation to perform can be qualified as the outer boundary of a right's ambit or as a limit to the allowance of the State to interfere with those rights. This scheme only awkwardly fits to the examination of a violation of the positive dimension of rights.

87 Grootboom (n. 37), para. 38 (on the right to have access to adequate housing according to Article 26 of the Constitution).

88 BVerfGE 33, 303-358, para. 63, Judgment of 18 July 1972 - 1 BvL $32 / 70$ and $25 / 71$ - Numerus clausus (on the right to university education). 
positive state action (which in German constitutional rights doctrine is called "Untermaßverbot"). State measures are not allowed to fall short of a minimum level in order to be considered "appropriate" or "reasonable". One can therefore argue that in certain situations, in the case of empirically demonstrated corruption in a State party, the prohibition of insufficient action requires the State not only to ratify the international anti-corruption instruments, but also to launch a national anti-corruption campaign and to formulate a preventive policy. ${ }^{89}$ The concepts of "appropriateness" and "reasonableness" thus play a dual role: They serve as the cap, but also as the floor. ${ }^{90}$ States must take "appropriate" measures - not more, but also not less.

The question now is when a State fails to meet that minimum level and what institution is empowered to make an authoritative determination thereof. Once again, the primary responsibility for assessing which means are appropriate and reasonable for realizing social rights lies with the State party itself. The State party must, as a first approach, decide what anti-corruption strategy it wants to formulate, what legislative measures it wants to take, what authorities it wants to establish, and what powers and financial resources it wants to grant that authority. In its settled case law, the CESCR emphasizes that the States parties have a substantial "margin of appreciation" in this regard..$^{91}$ The Optional Protocol expressly provides that a State party "may adopt a range of possible measures for the implementation of the rights set forth in the Covenant" (Article 8(4) OP). In the final instance, however, the CESCR reserves the right to review the "appropriateness" of the means and thus of the financial resources in an authoritative way ${ }^{92}$ - albeit without

89 See Boersma 2012 (n. 4), 233.

90 Cf. the Note prepared by the Secretariat of the Human Rights Council,

"The use of the 'reasonableness' test in assessing compliance with international human rights obligations", 1 February 2008, A/HRC/8/ WG.4/CRP.1.

91 CESCR, An Evaluation of the Obligation to Take Steps to the "Maximum of Available Resources" under an Optional Protocol to the Covenant Statement, UN Doc. E/C.12/2007/1 of 10 May 2007, paras. 11-12.

92 See CESCR, General Comment No. 3 (n. 44), para. 4; CESCR Statement the power to enforce its determination.

In summary, both particular corrupt acts by individual public officials as well as a completely insufficient or entirely lacking anti-corruption policy of a State on the whole may, in certain constellations, be conceptualized as a violation of concrete human rights, e.g., the right to health of concrete patients or the right to equal treatment of concrete business competitors. The greatest doctrinal obstacle in this regard is not causation or attribution, but - especially in the field of social rights - the "margin of appreciation" or "reasonableness".

2007 (n. 90), paras. 8 and 12. 


\section{Should corruption be conceptualized as a human rights violation?}

An entirely different set of questions concerns the proceedings in which such a human rights violation might be claimed and whether the change in perspective - away from a primarily criminal law approach to anti-corruption toward human rights - is practical in terms of legal policy and valuable in terms of legal ethics.

\section{Opportunity for moral and practical strengthening of the anti-corruption agenda}

Proponents of endowing the anti-corruption instruments with a human rights approach believe that this will upgrade these instruments in political and moral terms and thus ensure improved implementation of anti-corruption measures. ${ }^{93}$ The classical argument is "empowerment". The human rights approach can elucidate the rights of persons affected by corruption, such as the rights to safe drinking water and free primary education, and show them how, for instance, the misappropriation of public funds in those areas interferes with their enjoyment of the goods to which they are entitled. In that way, affected persons would be empowered to denounce corruption to which they otherwise would be helplessly exposed. ${ }^{94}$

The UN Human Rights Council believes that the greatest advantages consist, firstly, in shifting the existing criminal law focus of the anti-corruption instrument away from individual perpetrators toward the systemic responsibility of the State

93 See Pearson (n. 4), 46: "It is proposed here that, by examining the human rights cost of corruption, added weight is given to anti-corruption efforts, as well as to human rights protection"; Kumar (n. 80), 43: "Human rights approaches help in exposing violations, and empower victims [...] the moment corruption is recognized as a human rights violation, it creates a type of social, political and moral response that is not generated by crime [...]".

94 See Sepúlveda Carmona/Bacio Terracino, in: Boersma/Nelen (n. 34), 25-49, 48. and, secondly, in an improvement of the status of victims. ${ }^{95}$

A weakness of the purely criminal law approach to anti-corruption is becoming apparent especially in China, where the broad and indeterminate criminal offences can easily be abused to eliminate or at least discredit political opponents. ${ }^{96}$ The human rights perspective shifts the focus away from repression toward prevention ${ }^{97}$ and thus also away from the abusive initiation of criminal proceedings.

Finally, the shift from criminal law to human rights changes the intensity and burden of proof. While a public servant accused of bribery or criminal breach of trust enjoys the presumption of innocence, the human rights approach requires States to exonerate themselves before the treaty bodies when accused of deficient anti-corruption measures. For instance, a State must demonstrate that while it is willing to allot sufficient means to an authority, it is unable to do so due to a lack of resources. ${ }^{98}$ The follow-up question would be whether statistical evidence or the mere observation of the luxurious lifestyle of high-ranking politicians would be sufficient to corroborate the misappropriation of public funds that is presumed by the practice of the CESCR and

95 Along these lines, see Final Report of the Human Rights Council Advisory Committee on the issue of the negative impact of corruption on the enjoyment of human rights (UN Doc. A/HRC/28/73) of 5 January 2015, paras. 25 and 28.

96 The anti-corruption campaign was formally adopted by the 3rd Plenary Session of the 18th National Congress of the Communist Party in November 2013. The implementing institution is the Central Discipline Inspection Commission (Xuezhi Guo, Controlling Corruption in the Party: China's Central Discipline Inspection Commission, The China Quarterly 219 (2014), 597-624); http://thediplomat.com/tag/china-anti-corruption-campaign/; http://www.scmp.com/topics/xi-jinpings-anti-graftcampaign.

97 Prevention is also - independently of human rights considerations - one of the four pillars of UNCAC (Chapter II).

98 See CESCR, General Comment No. 3 (n. 44), para. 10; CESCR Statement 2007 (n. 90), para. 9. In regard to health protection, see CESCR, General Comment No. 14 (n. 83), para. 47. 
also by the UN Convention against Corruption. Article 20 UNCAC calls upon States parties to "consider" establishing "illicit enrichment" as a criminal offence. Under such a criminal law provision, a significant increase in the assets of a public official that he or she cannot reasonably explain in relation to his or her lawful income could be punished. Such an implicit presumption of guilt is problematic in terms of the rule of law.

\section{Practical recommendations}

The practical strategy implied by this change in perspective would be mutual mainstreaming. ${ }^{99}$ Human rights mainstreaming of anti-corruption efforts would mean that the realization of human rights would be one of the anti-corruption goals from the outset. In legal practice, this would imply an interpretation of all criminal offences relating to corruption in a way that takes into account human rights. On a complementary basis, anti-corruption mainstreaming of all human rights procedures should be implemented. ${ }^{100}$

The implementation of this recommendation would include the following: In the work of the human rights treaty bodies, the guidelines for all country reports and for all country-specific concluding observations of the committees as well as the mandates of the human rights special rapporteurs should include corruption as a checkpoint that must be addressed. Not only human rights NGOs, but also specialized anti-corruption NGOs should be allowed to participate in the Universal Periodic Review as well as in treaty-specific monitoring. One might also conceive of a "General Comment on Corruption and Human Rights" that would apply to all treaties. Finally, an anti-corruption mandate could be included in the international standards for the national

99 See, especially, International Council on Human Rights Policy and Transparency International (prepared by Magdalena Sepúlveda Carmona), Integrating Human Rights into the Anti-Corruption Agenda: Challenges, Possibilities and Opportunities (Geneva: International Council on Human Rights Policy 2010).

100 See Boersma 2012 (n. 4), 376-379. human rights institutions.

The practical benefit of the change in perspective is diminished, however, in that the international mechanisms are themselves weak when it comes to enforcing human rights. The options for individual complaints at the international level are limited - but some openings do exist, for example individual communications to various Human Rights Treaty Bodies. Of course, it should not be forgotten that the domestic institutions are the primary enforcers of international human rights. If a domestic court were to condemn organs of the State for a violation of human rights through corruption, this would be a comparatively strong sanction. In many States, however, this is not to be expected, due to corruption in the justice system. This means that "empowerment" through human rights remains more symbolic than practical.

\section{Risk of moral weakening}

The strength of taking a human rights approach to anti-corruption instruments is simultaneously its weakness, however. This is because of the ambivalent attitude of the Global South toward "Western" human rights. Their critique of the idea of human rights overlaps with fundamental objections to the international anti-corruption agenda.

This fundamental critique is clothed in the language of cultural relativism, ideology, or economics. ${ }^{101}$ According to the critique, the anti-corruption strategy is merely the imposition of a particular "Western" model of the State in numerous respects: A liberal State governed by the rule of law is required as a regulatory framework for a free market. This demand is based on a neoliberal agenda that wants to push back an interventionist, heavily bureaucratized model of the State.

101 See, e.g., David Kennedy, The International Anti-Corruption Campaign, Connecticut Journal of International Law 14 (1999), 455-465; Balakrishnan Rajagopal, Corruption, Legitimacy and Human Rights: The Dialectics of a Relationship, Connecticut Journal of International Law 14 (1999), 495-507. 
The critique accuses the "rule of law" of serving primarily the economic interests of property owners and of capital.

Secondly, according to this critique, the conception of corruption as an evil is based on the picture of a State that performs public duties by way of public officials who are hired on the basis of merit and who act according to legal rules that formally apply to all. But this disqualifies communities based on family and clan relationships, which are sustained by exchanging gifts and providing group members with official posts. The values of reciprocity and loyalty underlying these communities are not acknowledged, but rather are replaced with Western meritocratic thinking and formal equal treatment. The allegation of legal and cultural imperialism and of the dictate of Western capital is further nourished by the human rights approach to anti-corruption strategies. According to that view, both sets of international instruments are merely two variants of imperialism.

However, economic and anthropological research relativizes this fundamental critique of anti-corruption strategies and thus the danger that they might be weakened by imbuing them with a human rights approach. The allegation that both anti-corruption and human rights are hegemonic or US-dominated strategies and/or strategies driven by global capital sounds more like an attempt to justify the behaviour of elites whose power and sinecures are threatened by anti-corruption and by the demand for respect of human rights. Individuals affected in many different regions of the world and cultures have demonstrated on Tahrir Square or the Maidan, in Caracas or Mexico City, for freedom and fair prices of bread and against the corruption of the elites. 


\section{Conclusion and outlook}

\section{Shift in the prerogative of interpretation}

In terms of communication theory, the change in perspective proposed here is a kind of "framing", i.e., a new framework for interpretation associated with a new prerogative of interpretation. It is important in this regard that this prerogative of interpretation shifts in institutional terms as well: away from the World Bank and toward the UN Human Rights Council. Potentially, this new discursive power also entails a new power to act.

In legal terms, the connection between anti-corruption law and human rights protection proposed here can be construed as a systemic integration of two subareas of international law. Or, the human rights approach to anti-corruption instruments can be seen as their constitutionalization. Some international lawyers complain that the latter smacks of "human rightism", ${ }^{102}$ or of a "hubris" of international human rights protection. ${ }^{103}$ But this alleged hubris can also be seen in more positive terms as the legitimate reinstitution of the human being as the normative reference point for all law, including international law.

\section{Devaluation of the Global South?}

We have seen that the determination of a concrete violation of human rights by a concrete corrupt act is easier in the domain of petty corruption. In the domain of grand corruption, such as bribery of government ministers by foreign investors or the diversion of funds from the public budget, the connection between corrupt conduct and human rights violations of concrete victims is much harder to make. Now Western democracies suffer less from petty corruption than from grand corruption, including what is provocatively

102 See Alain Pellet, “Human Rightism” and International Law, Italian Yearbook of International Law 10 (2003), 3-16.

103 See Eric Posner, The Twilight of Human Rights Law (Oxford: OUP 2014), 148. termed "legal corruption"104 in the form of non-transparent election financing and the resulting vested interests of politics, or in the form of a toleration of the smooth transition of public officials to lucrative jobs in the private sector, in which the insider knowledge gained in office can be put to use in the new company ("revolving door" phenomenon).

Because the reconceptualization in terms of human rights focuses primarily on petty corruption, it casts a spotlight on the Global South. But it would be exaggerated to say that this spotlight constitutes a devaluation of non-Western societies and thus represents a paternalistic, civilizing mission of the West against the rest of the world. The change in perspective does not downplay or excuse grand corruption, including "legal" corruption in the Western world. It is merely less able to capture it, because grand corruption has a different, less individualized structure of wrongfulness.

\section{The State, public office, and universalizability}

Until well into the 19th century, patronage and the purchase of public offices were largely considered legal and legitimate components of governance even in Europe. ${ }^{105}$ The awareness that these forms of exercising and influencing political power and administration were illegitimate and to be combated could only emerge with the development of the modern State - a State in which an impartial bureaucracy is called upon to apply the law equally and in which all public

104 See Daniel Kaufmann/Pedro C. Vincente, Legal Corruption, Economics and Politics 23 (2011), 195-219.

105 See Renate Bridenthal, Introduction, in: Bridenthal (ed.), The Hidden History of Crime, Corruption, and States (New York: Berghahn Publishers 2013), 1-22, 4; Jacob van Klaveren, Corruption as a Historical Phenomenon, in: Arnold J. Heidenheimer and Michael Johnston (eds.), Political Corruption: Concepts and Contexts (New Brunswick: NJ: Transaction Publishers 2002), 83-94. The situation is different for bribery than for patronage and the purchase of public offices. Indications of proscriptions against bribery can already be found in antique legal cultures. 
officials are required to act in the public interest, not in the interest of their family or ethnic group.

In a patrimonial State in which the political and administrative positions are primarily intended to generate income ("rent seeking"), the idea of corruption has no place. In that sense - as already indicated at the outset - the modern State governed by the rule of law and the concept of corruption are inextricably linked. This also explains why anti-corruption is difficult in regions of the world where this understanding of the State and the associated institutional safeguards are weak.

But - to use an example - is it really the same from the perspective of a motorist whether the sum of money he or she has to pay at a road block in order to pursue his or her course represents a bribe to a corrupt traffic police officer - as in many African States - or a motorway toll - as in France for example?

In both cases, the motorist's freedom of movement is limited by him being forced to pay. The difference is that the motorway toll is based on a law that serves the public interest, namely maintenance of the motorway network, and at the same time applies equally to everyone (with reasonable differences based on type of vehicle, number of persons, or other relevant criteria). In contrast, the bribe is not based on a fee schedule defined in a political or at least orderly administrative procedure - but it may under certain circumstances help feed the police officer's family. The difference between a bribe and a State fee is thus based solely on the legitimacy and legality of the institutions and procedures in which they are defined, collected, and used.

Augustine's insight that States not governed by law and justice are nothing but large bands of thieves has lost none of its validity after more than 1,000 years. ${ }^{106}$ Only if this insight proves to be universally applicable can a global anti-corruption

106 See Aurelius Augustinus, De Civitate Dei (Leipzig: Teubner 1872 (original c. 413), Book IV, p. 4, 1: "Remota itaque iustitia quid sunt regna nisi magna latrocinia?" strategy be successful. And the "individualized" conception of corruption - namely the insight that corruption interferes with the rights of each individual citizen - can make a greater contribution to this universalization than the invocation of an anonymous general interest and an abstract conception of public office. 


\section{Notes}




\section{Basel Institute on Governance}

The Basel Institute on Governance is an independent non-profit competence centre specialised in corruption prevention and public governance, corporate governance and compliance, anti-money laundering, criminal law enforcement and the recovery of stolen assets. Based in Switzerland, the Institute's multidisciplinary and international team works around the world with public and private organisations towards its mission of combating financial crime and tangibly improving the quality of governance globally.

\section{Working papers}

In this working paper series the Basel Institute on Governance publishes reports by staff members and invited international experts, covering critical issues of governance theory and practice. For a list of publications, please visit www.baselgovernance.org. 


\section{CONTACT}

Anne Peters

Prof. Dr. iur., L.L.M. (Harvard)

apeters-office@mpil.de

Basel Institute on Governance

Steinenring 60,

4051 Basel, Switzerland

www.baselgovernance.org

info@baselgovernance.org

ISSN: 2624-9650

\section{Abstract}

It is a fact that states with a high corruption rate (or a high corruption perception) are at the same time those with a bad human rights situation. Beyond this coincidence, the paper seeks to identify a concrete legal relationship between corruption and deficient human rights protection. This seems relevant and practical terms, because the extant international norms against corruption have so far yielded only modest success; their implementation could be improved with the help of human rights arguments and instruments.

This paper therefore discusses a dual question: Can corrupt behaviour be conceptualised as a human rights violation? Should corrupt behaviour be categorised and sanctioned as a human rights violation? My answer is that such a juridic reconstruction is plausible under specific conditions, especially for petty corruption, but that we should be aware of the risks of such reframing of the issue. 